\title{
THE EFFECTIVENESS OF USING TASK BASED LANGUAGE TEACHING (TBLT) IN TEACHING THE STUDENTS' ENGLISH \\ SPEAKING ABILITY AT THE ELEVENTH GRADE OF SMK PENERBANGAN AAG ADISUTJIPTO YOGYAKARTA
}

\author{
Yasmika Baihaqi \\ English Department of FKIP UM Metro Lampung \\ yasmikabaihaqibaihaqi@yahoo.co.id
}

\begin{abstract}
:
This study is intended to find out that the task based language teaching method is effective in improving the students' speaking ability at the eleventh grade students of SMK Penerbangan AAG Adisutjipto Yogyakarta in the academic year 2012/ 2013. The population of this research is the eleventh grade students of SMK Penerbangan AAG Adisutjipto Yogyakarta in the academic year 2012/2013. The researcher in this case takes two intact classes with a total number of 63 students selected as the samples of the study. To collect the data, the researcher utilizes a test and questionnaire. The test is employed to reveal the students' speaking ability while the questionnaire is used to collect the data of the students' learning activities during the teaching and learning process. The data are analyzed utilizing descriptive and inferential statistics. The task based language teaching (TBLT) method is effective on the students' speaking ability at the eleventh grade students of SMK Penerbangan AAG Adisutjipto Yogyakarta in the academic year 2012/ 2013. It is supported from the mean of the pre test and post test for experimental group and control group. This study yields the mean in pre-test for experimental group is 37.13 and 34.71 for control group. In the post test, the mean of the experimental group becomes 69.13 and 37.94 for control group. The t-test value showed 20.509 with the degree of freedom 62 . It was higher than the value of t-table (2.000) at the significant level of 0.05 . It means that TBLT method is more effective than teacher's own method to teach speaking.
\end{abstract}

Key words: TBLT, Speaking Ability, Teaching and Learning Process. 


\section{INTRODUCTION}

According to Oxford dictionary (A.S. Hornby, 1995), speaking is the action of conveying information or expressing one's thoughts and feelings in spoken language. From the definition, it concludes that speaking is expression in sending messages from a speaker towards listeners. Sending message in speaking uses verbal language. Because of that, communication in speaking way should be accurate. The accuracy will decide the success of communication. Learning process requires that the goal of teaching speaking should improve students' communicative skills because students can express themselves and learn how to use a language. For this case, students should master several speaking components, such as: comprehension, pronunciation, grammar, vocabulary, and fluency. English teacher should be creative in developing their teaching learning process to create good atmosphere, improve the students speaking skill, give attention to the speaking components', and make the English lesson more exiting.

Task-based language teaching (TBLT) is an approach to foreign language learning and teaching and a teaching methodology in which classroom tasks constitute the main focus of instruction. The primary focus of classroom activity is the task and language is the instrument which the students use to complete it. The task is an activity in which students use language to achieve a specific outcome. The activity reflects real life and learners focus on meaning; they are free to use any language they want.

In task based language teaching, teachers have a lot of opportunities to develop various activities. Teacher can use fun activities with familiar topics to students. The familiarity of topic and the enjoyment in conducting the task is the solution of students' low participation in speaking class. Task-based learning technique gives a greater chance to speak and communicate in the target language.

\section{METHODOLOGY}

The current study adopted the true-experimental design in terms of using one experimental class and one control class. The experimental group is taught using the taskbased language teaching designed by the researcher and the control group was taught using the conventional method of teaching used by teachers of foreign language at the school.

This research using pretest-posttest designs, and is a useful way of ensuring that an experiment has a strong level of internal validity. The principle behind this design involves 
two groups, a test group and a control. Both groups are pre-tested, and both are post-tested, the ultimate difference being that one group was administered the treatment. This test allows a number of distinct analyses, giving researcher the tools to filter out experimental noise and confounding variables. The internal validity of this design is strong, because the pretest ensures that the groups are equivalent. The data of this research is quantitative. The research methodology including; the subject of the research, the instrument of the research, the procedure of the research, technique of collecting data and the technique of analyzing data.

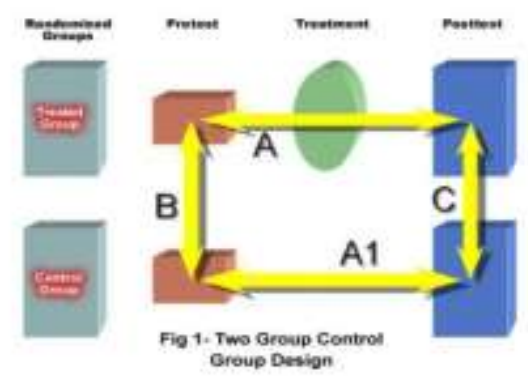

Martyn Shuttleworth (2009)

a. This design allows researchers to compare the final posttest results between the two groups, giving them an idea of the overall effectiveness of the intervention or treatment. (C)

b. The researcher can see how both groups changed from pretest to posttest, whether one, both or neither improved over time. If the control group also showed a significant improvement, then the researcher must attempt to uncover the reasons behind this. (A and A1)

c. The researchers can compare the scores in the two pretest groups, to ensure that the randomization process was effective. (B)

\section{RESULT AND FINDING}

In this section, the researcher discusses the research findings which includes the meaning the test result and the effectiveness of the treatment. The aim of the study is find out that the task based language teaching method is effective on the students' speaking ability at the eleventh grade students of SMK Penerbangan AAG Adisutjipto Yogyakarta in the academic year 2012/ 2013. 
In the pre-test, the average score of the experimental group and the control group are 37.13 and 37.71. The result of the post test of the experimental group is higher than the control group; they are 69.13 for the experimental group and 37.94 for the control group. From the score of two groups, the result shows that the experimental group is the better than the control group. The hypothesis testing indicates that the experimental group is significantly higher than the control group. Based on the result of the investigation, it is found that there is significant different in speaking ability between students taught using TBLT method and using other methods. The experimental group of which the increasing mean score of speaking ability was higher than control group showed this. It can be seen that the value of t obtained (to) is higher than the value of $t$ table at the significant level of 0.05 .

The TBLT method is more effective than teacher's own method in teaching speaking because of some reasons:

Firstly, the TBLT method offers an alternative method for language teachers in language teaching and learning to teach speaking. In a task-based lesson the teacher does not predetermine what language will be studied, the lesson is based around the completion of a central task and the language studied is determined by what happens as the students complete it. Task-based language teaching method is an ideal tool for implementing these principles in the foreign language classroom.

Secondly, teachers have a lot of opportunities to develop various activities. Teacher can use fun activities with familiar topics to students. The familiarity of topic and the enjoyment in conducting the task is the solution of students' low participation in speaking class. Task-based learning technique gives a greater chance to speak and communicate in the target language. It is related to the theory proposed by Nunan (1989) that state task based approach to communicative instruction which leave teachers and learners free to find their own procedures to maximize effectiveness.

Thirdly, Richards and Rodgers (2001) assert that "task-based language teaching refers to an approach based on the use of tasks as the core units of planning and instruction in language teaching". The activity reflects real life and learners focus on meaning; they are free to use any language they want. The teachers can help students learn to speak so that the students can use speaking to learn because it is impossible to teach speaking without any interaction between speaker and listener. As Brown (1994) stated, speaking is an interactive process of constructing meaning that involves producing and receiving and processing information. The important factor in the speaking process is understanding. It means that the listener can understand what the speaker says. The listener sometimes does not know all the meaning of 
the words used by the speaker; however, he/she can understand the meaning of the ideas expressed by the speaker. It is indicated that speaker has been successful to convey the information to the listener.

Further, as Lado (1961) pointed out, speaking ability is described as the ability to report acts or situation, in precise words, or the ability to converse or to express a sequence of ideas fluently. The students with good speaking ability can be influenced by people that are capable to express their idea, thought and feelings as clear as possible. Besides a good attitude in a speaking and pronouncing the word correctly is also important thing to make a good speaking because communication can be required by people that understand about what other people say. Through TBLT method, the teacher gives some freedom in approaching the problem or objective.

In the other hand, in the control class the researcher used traditional method to teach English in the class namely; a speech, memorizing and doing the exercises. Teaching is a dynamic activity. Teachers need to know their students well and be able to adapt their teaching styles to a particular classroom and to individual students. Effective teaching requires good teaching methods.

Traditional approaches at their best encourage people to learn from and conform to the best practice of the past. Hence they are often conservative. They often have a somewhat pessimistic view of human nature (which they believe needs to be controlled) and do not believe that radically changing society or institutions will change people. Learning is not fun and discipline is needed to help encourage self-control and responsibility. They usually use traditional teaching and training methods. The curriculum is set by the institution, not the learners. This is a teacher-centered approach. Traditional universities are a good example of conventional approaches to education practice. Particularly negative sides of conventional approaches to education and training are authoritarianism, paternalis m, and elitism.

Traditional teaching methods are deemed restricted to some degree. Traditionally, classroom settings are teacher-centered where the teacher often talks at the students instead of encouraging them to interact, ask questions or make them understand the lesson thoroughly. Most classes involve rote learning, where students depend on memorization without having a complete understanding of the subject. Just by passing the tests, consisting of descriptions, matching and other forms of indicators are all that matter to complete the curriculum. Long lectures and dictations, rote memorization and little interaction in the classroom often leave students less attentive and less engaged. They are prone to skipping classes and missing 
lessons altogether. Moreover, students in a traditional class have little opportunity to interact with their classmates or their teacher.

Traditional teaching is concerned with the teacher being the controller of the learning environment. Power and responsibility are held by the teacher and they play the role of instructor (in the form of lectures) and decision maker (in regards to curriculum content and specific outcomes). They regard students as having knowledge holes that need to be filled with information. The following are some of the disadvantages of lecture method and memorizing which is used to teach English in the control class;

1. Some of the students may already know the content of the lecture while some may not be ready for the lecture.

2. It is difficult to maintain student interest and attention for a full hour of lecture.

3. The communication is mostly one-way communication from the teacher to the students. Usually there is little student participation.

4. Most students have not learned to take good notes.

5. Lecture information is forgotten quickly, during and after the lecture.

6. Lectures are not effective when teaching thinking objectives.

7. The lecture method encourages student dependence on the teacher.

8. Few teachers have been taught how to lecture effectively.

9. Students are not very active when only listening.

As students, they never question the effectiveness of the education system. They taught to assume that it is serving their needs. They are brainwashed into thinking that the way teachers teach is good for us. Fact is, since elementary students have taught been asked to do way too much memorization. This is not good; students do not learn when all that is required of them is retaining insignificant facts. These facts have little if any worth after the test is taken.

This teaching method very popular because it is an easier way for the teacher to educate. However, students suffer immensely, when teachers take the easy route. Too many classes only teach students to only remember the bare minimum required for a test. When this happens, the students avoid the key concepts and instead attempt to remember facts and equations, effectively avoiding the point of school, to learn skills which are transferable. If all that is expected is memorization, then the tests only evaluate memory. Tests that only ask 
students to recall facts are not good culminating assessments, and they may not accurately evaluate the students.

To be fair, some memorization is required in school, but the idea of immersing students in facts, and then expecting them to do well on a test is absurd. More active and hands-on learning methods are required. Students need activities that require thinking skills.

\section{CONCLUSION AND SUGGESTION}

The task based language teaching (TBLT) method is effective on the students' speaking ability at the eleventh grade students of SMK Penerbangan AAG Adisutjipto Yogyakarta in the academic year 2012/ 2013. It is supported from the mean of the pre test and post test for experimental group and control group. The mean in pre-test for experimental group was 37.13 and 34.71 for control group. In the post test, the mean of the experimental group becomes 69.13 and 37.94 for control group. The t-test value showed 20.509 with the degree of freedom 62. It was higher than the value of t-table (2.000) at the significant level of 0.05. It means that TBLT method is more effective than teacher's own method to teach speaking.

In the term of research findings, the researcher would like to offer three kinds of suggestions, namely, suggestions for the teachers, students, and other researchers.

a. Suggestion for the Students

Task-based language teaching method (TBLT) gives a greater chance to speak and communicate in the target language so the students should be active and creative in teaching and learning process because they can free to express their ideas. In learning activity, the students must not feel bored since the students' interest and self confident become important factor to the success of speaking ability. Doing fun activities can become solution to overcome the boredom in the class.

b. Suggestion for the Teachers

Task based language teaching method (TBLT) is a different way to teach languages. The teachers must have preparations before teaching speaking. To raise the students' interest 
in studying English, the teacher can apply TBLT in teaching speaking so that the students will be much more interested in learning English and they will enjoy learning English and have self confidence to speak English.

c. Suggestion for Other Researchers

There are still many cases concerning this problem that the writer has not observed. Therefore, the writer would like to suggest that other researchers analyze other cases of teaching speaking such as the way or strategy to study speaking efficiently and effectively. Therefore, conducting more comprehensive study is necessary for the sake of developing an effective teaching strategy to teach English speaking.

\section{REFERENCES}

Brown, Douglas. (1994). Principles of language learning and teaching. California: San Frasisco State University.

(1994). Teaching by principles: an interactive approach to language pedagogy. Englewood Cliffs, New Jersey: Prentice Hall Regents.

Hornby, A.S. (1995). Oxford Advanced Learner's Dictionary of Current English. Oxford: Oxford University Press.

Lado, R. (1961). Language Testing: The Construction and Use of Foreign Language Tests. London: Longman.

Martyn. S. (2009). Pretest-Posttest Designs. http://www.experiment-resources. com/pretestposttest-designs.html. Retrieved 11 Oct. 2012.

Nunan, D. (1989). Designing Task for the Communicative Classroom. Cambridge; Cambridge University Press.

Richards, J. \& Rodgers, T.(2001). Approaches and Methods in Language Teaching. Cambrid ge: Cambridge University Press. 